Bakgrunn: Smertebehandling til opioidavhengige er krevende fordi opioidavhengighet stimulerer nevropsykologiske, atferdsmessige og sosiale responser, som igjen forsterker smerteopplevelsen og kompliserer adekvat smertelindring. Helsepersonells kunnskaper, rutiner og holdninger er faktorer som kan påvirke smertebehandling til opioidavhengige.

Hensikt: Kartlegge helsepersonells handlinger, kunnskaper og holdninger til opioidavhengige med smerte innlagt i norske sykehus.

Metode: Beskrivende tverrsnittsdesign basert på en survey med et hensiktsmessig utvalg. Av 435 utsendte spørreskjema ble 312 besvart (72 prosent). Utvalget besto av sykepleiere og leger ved kirurgisk, medisinsk, intensiv-og anestesiavdelinger ved fire sykehus.

Resultater: Et mindretall (38 prosent) av respondentene oppga at de kartla pasientenes rusmisbruk. $0 \mathrm{~m}$ lag halvparten (47 prosent) svarte at de ga pasientene opioidsubstitusjon for å forhindre abstinenser. Femtito prosent anvendte aldri smertekartleggingsverktøy. Resultatene viste et egenvurdert kunnskapsnivå på under 3,0 (fempunktsskala med 5 som høyeste verdi). Flertallet $[56,1$ prosent) av sykepleierne og en sjettedel (15,8 prosent) av legene følte seg manipulert av opioidavhengige pasienter. Et mindretall $(20,8$ prosent av sykepleierne og 26,3 prosent av legenel trodde på pasientens smerteformidling. Godt over halvparten av respondentene (55,7 prosent av sykepleierne og 73,7 prosent av legene) var enige i påstanden om at opioidavhengighet er en sykdom.

Konklusjon: Fordi helsepersonells holdninger til en viss grad synes å trekke pasientens troverdighet i tvil, er det behov for videre studier for å undersøke om opoidavhengige pasienter faktisk får adekvat smertebehandling når de er innlagt i sykehus.

\section{Treatment of drug addicts with} pain in hospital

Background: Pain management of opioid-dependent patients is challenging, as drug-addiction stimulates neuro-psychological, behavioural and social responses that enhance the experience of pain, and complicates adequate pain relief. Health professionals" knowledge, routine as well as attitudes, are factors that could affect pain treatment of opioid-dependent patients.

Purpose: Describe health personnel"s interventions, knowledge and attitudes against opioiddependent patients in pain.

Method: A descriptive cross-sectional survey with an appropriate selection, where $312(72 \%)$ out of 435 distributed questionnaires were answered. The sample includes all physicians and nurses from surgical, medical and intensive care/ anaesthesia units at four hospitals.

Results: A minority (38 \%) of respondents stated that they perform detection of the patient"s drug abuse. About half of the respondents (47\%) replaced the patient"s daily use of opioids. Fifty-two percent answered that they never used pain assessment tools. The results showed self-assessed knowledge level of less than 3.0 (from a fivepoint scale with 5 as highest). The majority (56.1\%) of the nurses and one-sixth (15.8\%) of the physicians responded that they felt manipula- ted by opioid-dependent patients, while $20.8 \%$ of the nurses and 26.3 $\%$ of the physicians responded that they believed in the patient"s pain presentation. A narrow majority of the nurses (55.7\%) and $73.7 \%$ of the physicians agreed that drug addiction is a disease.

Conclusion: Even though health care personnel"s attitudes to a certain extent seem to doubt the patient"s credibility, there is a need for further studies to explore whether the opioid-dependent patients receive appropriate pain treatment when hospitalized.

Key words: Pain, quantitative study, survey, illicit drug abuse, inpatient management 


\section{Smertebehandling av rus- misbrukere innlagt i sykehus}

Forfattere: Rita Li, Randi Andenæs, Eva Undall og Dagfinn Nåden

\section{NøKKELORD}

- Smerte

- Kvantitativ studie

- Spørreundersøkelse

- Rusmiddel

- Spesialisthelsetjeneste.

\section{INTRODUKSJON}

Rusavhengighet utgjør et stort globalt helseproblem. Internasjonale studier viser at rusmiddelrelaterte sykdommer og skader gir hyppige sykehusinnleggelser $(1,2)$. Smertebehandling til opioidavhengige er spesielt krevende fordi opioidavhengighet stimulerer nevropsykologiske, atferdsmessige og sosiale responser, som igjen forsterker smerteopplevelsen og kompliserer adekvat smertelindring (2).

Verdens helseorganisasjon (3) definerer rusmiddelavhengighet som et syndrom bestående av kognitive, atferdsmessige og fysiologiske symptomer, som indikerer at en person har nedsatt kontroll på bruk av rusmidler. Ved langvarig tilførsel av opioider oppstår endringer i sentralnervesystemet som ledsages av øt toleranse for opioider, økt følsomhet for smerte (hyperalgesi), abstinensreaksjoner ved opphør av opioidtilførsel, og endringer i motivasjonsbanene i hjernen (2). Opioidavhengige er rusavhengige som har utviklet et avhengighetsforhold til opioider. Hos disse kan smerte i kombinasjon med abstinenser som følge av manglende tilførsel av opioider føre til angst, aggressivitet og sterk uro. Når de er innlagt i sykehus vil disse pasientene ikke sjelden skrive seg ut på eget ansvar før den medisinske behandlingen er avsluttet $(6,4,5)$.

Mens det foreligger omfattende forskning om smerte og smertelindring av pasienter generelt, er forskningen som omhandler smertebehandling av pasienter med rusavhengighet begrenset. Utilfredsstillende smertelindring til pasienter i sykehus er imidlertid godt dokumentert (7), noe som forsterkes når pasienten har eller har hatt et rusmisbruk $(11,8)$. Det er også vist at smertelindring til opioidavhengige er suboptimal eller ikke-eksisterende $(6,9)$. Mangelfulle kunnskaper om hvordan opioidavhengighet påvirker smertebehandling har vist seg å være en vesentlig årsak til utilstrekkelig smertelindring $(8,10,7)$. I tillegg til at opioidavhengige pasienter gis utilfredsstillende smertebehandling, blir de også stigmatisert og smertene blir underdiagnostisert
$(31,12,13)$. I en studie fra 2003 (14) konkluderte forfatterne med at manglende smertelindring til opioidavhengige pasienter ikke bare må forstås ut fra kunnskapsmangel og dårlige rutiner, men like mye ut fra helsepersonells stereotype holdninger og deres påvirkning på handlingsvalg. Det kan synes som om helsepersonell er redde for å bli manipulert og lurt. Dette gjelder spesielt ved etterspørsel og foreskrivning av opioider (10).

Handlinger, kunnskap

og

\section{Hva tilfører artikkelen?}

Resultatene i denne studien indikerer at det kan være behov for holdningsendrende tiltak, undervisning og klinisk integrert læring for å øke helsepersonells kunnskaper om smertebehandling av rusmisbrukere innlagt i sykehus.

Mer om forfatterne:

Rita Li er intensivsykepleier og høgskolelektor ved Høgskolen i Telemark, Fakultet for helse, Institutt for sykepleie. Randi Andenæs er førsteamanuensis ved Høgskolen i Oslo og Akershus, Fakultet for helsefag, Institutt for sykepleie. Eva Undall er intensivsykepleier og leder for smerteenheten ved STHF. Dagfinn Nåden er professor ved Høgskolen i Oslo og Akershus, Fakultet for helsefag, Institutt for sykepleie. Kontakt: rita.liahit.no. 
holdninger er komponenter som er sterkt forbundet med hverandre, og som påvirker helsepersonells beslutningsprosesser (17). Kunnskap er en av helsepersonells viktigste ressurser. $\AA$ omsette kunnskap til handling er av stor betydning for behandling og ivaretakelse av pasienter (21). Hvorvidt handlingen er relevant og imøtekommer pasientens behov, avhenger av at helsepersonell har en bevisst oppfatning av sine holdninger og de faktorer som inngår i holdningsbegrepet. Holdninger er relativt stabile og organiserte oppfatninger (kognitiv komponent), følelser (affektiv komponent) og handlingsintensjoner (atferdssentrert kompo- må vurderes ut fra biologiske faktorer, men også ut fra psykologiske, sosiale og kulturelle faktorer. En profesjonell tilnærming er å tro på pasienten, og ikke betvile hans rapportering av smerte. Klinisk erfaring viser at opioidavhengige pasienter samarbeider godt og snakker sant om sitt misbruk dersom helsepersonell viser dem respekt og oppnår tillit $(2,9)$. Effektiv smertelindring til opioidavhengige i sykehus er avhengig av et godt tverrfaglig samarbeid (9) der sykepleieren både har selvstendige og delegerte oppgaver. Leger og sykepleiere har flere overlappende funksjoner i smertebehandlingen, der leger har det medisinskfaglige ansvar og best

\section{Kunnskap er en viktig faktor i dannelse og endring av holdninger.}

nent) overfor objekter og saker av sosial art og betydning $(18,19)$. Kunnskap er en viktig faktor i dannelse og endring av holdninger. Holdninger kan være en måte å uttrykke sentrale verdier på, og de har ulik grad av høyt eller lavt endringspotensial (18).

I de faglige retningslinjene for norske leger framgår det at det er helt essensielt å kartlegge bruks- og avhengighetstype for å forebygge abstinenser og for å kunne gi adekvat smertelindring (5). Oppretting av et gjensidig tillitsforhold mellom helsepersonell og opioidavhengige er et annet overordnet mål ved behandlingstilbudet i sykehus $(2,4,5)$. Opioidavhengige pasienter har derimot ofte dårlig erfaring med smertelindring og abstinensbehandling på sykehus, og kan ha en forventning om å bli stigmatisert og mistrodd $(5,6,8,20)$. Både akutt og langvarig smerte er en kompleks sensorisk og følelsesmessig opplevelse som ikke bare behandlingskompetanse (16). opp legens forordninger, og har dermed en spesiell nøkkelrolle på grunn av sin nærhet til pasienten $(8,26)$.

Oversiktsartikler fra 2009 $(2,22)$ oppsummerer at det er lite empiri som ligger til grunn for håndtering av smerte hos opioidavhengige pasienter. Mye av den kunnskapen som foreligger er ikke-vitenskapelig og er basert på case rapporter, retrospektive studier og ekspertuttalelser. Disse studiene har ikke bidratt med kunnskap om hvordan helsepersonell selv vurderer smertebehandlingen av denne pasientgruppen. Gjennomgang av forskningslitteratur viser at det ikke foreligger studier som kartlegger handlinger, kunnskaper pleiere. Hensikten med studien er således å få kunnskap om disse forhold. Følgende tre forskningsspørsmål søktes besvart: Sykepleieren utfører og følger og holdninger hos leger og syke-
- I hvilken grad utføres sentrale handlinger når opioidavhengige pasienter med smerte er innlagt i sykehus?

- Hvordan vurderer leger og sykepleiere sin kunnskap om rusmisbruk og smerte?

- Hvilke holdninger har leger og sykepleiere til opioidavhengige pasienter med smerte?

\section{METODE}

Studien har et beskrivende tverrsnittdesign med et hensiktsmessig utvalg. For å sikre et representativt utvalg som kunne bidra med informasjon til å besvare problemstillingen, kartla kontaktpersoner innenfor smertemiljøet ved de enkelte sykehus hvilke avdelinger opioidavhengige pasienter oftest var innlagt i. På bakgrunn av denne kartleggingen valgte vi å forespørre alle leger og sykepleiere ansatt ved seks medisinske, tre kirurgiske og tre intensiv- eller anestesiavdelinger ved fire norske sykehus i fire ulike helseregioner. Inklusjonskriteriene var at respondentene skulle være sykepleiere eller leger i fulltidseller deltidsstilling, arbeide på en av de ovenfor nevnte avdelingene, samt ha erfaring med rusmisbrukere. Det ble delt ut totalt 456 spørreskjemaer sammen med et informasjonsskriv om studien, til 375 sykepleiere og 81 leger. Anonymiteten ble ivaretatt ved at spørreskjemaer ble delt ut eller lagt i de enkeltes posthyller. Det ble lagt ved konvolutter som spørreskjemaet skulle legges $i$, og som skulle lukkes etter utfylling. Innsamling av data pågikk i uke 41 og 42 i 2009. Allmenne forskningsetiske prinsipper ble fulgt (33). Studien ble meldt til og godkjent av Personvernombudet for forskning, Norsk samfunnsvitenskapelig datatjeneste A/S (NSD). 


\section{Spørreskjema}

Vi ønsket primært å bruke et allerede validert spørreskjema, men fant ingen som dekket formålet med studien. Vi utarbeidet derfor et eget spørreskjema tilpasset forskningsspørsmålene. Skjemaet besto av totalt 36 spørsmål inndelt i fire bolker som inkluderte bakgrunnsvariabler, handlinger eller tiltak som kan iverksettes overfor pasienter med rusmisbruk og smerter, samt helsepersonells kunnskaper om og holdninger overfor denne pasientkategorien.

I. Bakgrunnsvariablene omhandlet spørsmål om profesjon (lege/sykepleier), alderskategori (34 år eller yngre, mellom 35-49 år, 50 år eller eldre), hvilken avdeling de arbeidet på (kirurgisk, medisinsk, intensiv/ anestesi, eller annen sykehusavdeling), profesjonell erfaring (5 år eller mindre, mellom 5-15 år, 15 år eller mer), samt hvor ofte de var i kontakt med rusmisbrukere, kategorisert i følgende fire svaralternativer: 1) én gang per uke eller oftere, 2) én gang per måned eller oftere, 3) én gang per halvår eller oftere, eller 4) sjeldnere enn én gang per år.

II. Handlingsbolken besto av syv påstander som omhandlet handlinger vedrørende kartlegging av rusmisbruk og smerter, urin/blodprøvetaking, individuell behandlingsplan og samarbeid med annet helsepersonell (LAR, fastlege, kommune). Påstandene hadde fem svaralternativer; "aldri", "sjelden", "av og til", "ganske ofte" og "svært ofte".

III. Kunnskapsbolken besto av to deler. Del én besto av fem spørsmål (se tabell 2) hvor respondentene ble bedt om å vurdere egen kunnskap på en Likert-skala (fra 1=lite kunnskap til $5=$ mye kunnskap). I den andre delen ble respondentenes faktiske kunnskaper testet gjennom følgende tre kunnskapsspørsmål: 1) "Rusmisbrukere har høy toleranse for opioider", 2) "langvarig opioidbruk kan medføre hyperalgesi" og 3) "rusmisbrukere må ha store doser opioider for å oppnå effekt". Svaralternativene var "enig", "uenig" eller "vet ikke".

VI: Holdningsbegrepet ble operasjonalisert ut fra en tredelt inndeling med en kognitiv, affektiv og atferdssentrert komponent som beskrevet i introduksjonen $(18,19)$. Holdningsbolken inneholdt 16 påstander der svaralternativene var " $1=$ helt enig", " 2 =nokså enig", "3=både/og", "4=nokså uenig" og " $5=$ helt uenig". Cronbachs alpha for totalskåren i holdningsbolken var 0,66.

En anestesilege kvalitetssikret det medisinskfaglige innholdet. Vi gjorde også en pilotstudie blant seks sykepleiere og tre anestesileger for å teste om spørsmålene var klart og konsist formulert. Pilotstudien medførte ingen strukturelle eller innholdsmessige endringer av spørreskjemaet.

\section{Statistiske analyser}

Data ble analysert ved hjelp av statistikkprogrammet SPSS 17.0. Det ble anvendt beskrivende statistikk, frekvenstabeller, og kalkulering av gjennomsnittsverdi og standardavvik. Det ble beregnet prosentvise korrekte svar på hvert av de tre kunnskapsspørsmålene både i det samlede utvalget og deretter blant legene, og blant sykepleierne. Forskjeller mellom legene og sykepleierne ble undersøkt med kji-kvadrattest. Forskjell i skår mellom sykepleiere og leger ble undersøkt med students t-test, og funnene er rapportert med t- og p-verdier. Signifikansnivået ble satt til $5 \%$ ( 0,05 ). Det ble regnet ut totalskår for holdningsbolken, og her ble intern konsistens kalkulert ved hjelp av Cronbach alpha.

\section{RESULTATER}

Av 435 utsendte spørreskjema ble 312 besvart (72 prosent). Av disse besvarte 274 sykepleiere og 38 leger spørreskjemaet. Aldersgruppen 34 år eller yngre var den største. De som arbeidet på medisinske avdelinger utgjorde

TABELL 1: Karakteristikk over respondentene i spørreundersøkelsen $(n=312)$.

$\begin{array}{lll}\begin{array}{ll}\text { Bakgrunnsvariabler } \\ \text { Profesjon: }\end{array} & \text { Sykepleier } & \mathbf{N}(\%) \\ & \text { Lege } & 274(88,1) \\ \text { Alder: } & \leq 34 \text { år } & 145(11,9) \\ & 35-49 \text { år } & 125(39,7) \\ & \geq 50 \text { år } & 43(13,8) \\ \text { Type avdeling } & \text { Kirurgisk } & 76(24,4) \\ & \text { Medisinsk } & 140(44,7) \\ & \text { Intensiv/anestesi } & 77(24,8) \\ \text { Profesjonell erfaring } & \text { Andre } & 17(5,5) \\ & \leq 5 \text { år } & 94(30,1) \\ & 5-15 \text { år } & 145(46,2) \\ \text { Hvor ofte i kontakt } & \geq 15 \text { år } & 74(23,7) \\ \text { med rusmisbrukere i arbeidet? } & 1 \text { gang pr. uke eller oftere } & 89(29,0) \\ & 1 \text { gang pr. måned eller oftere } & 141(45,9) \\ & 1 \text { gang pr. halvår eller oftere } & 68(22,1)\end{array}$


TABELL 2: Egenvurdering av kunnskap om rusmisbruk, forskjeller mellom sykepleiere og leger $(\mathrm{N}=312)$.

\begin{tabular}{|c|c|c|c|c|c|c|}
\hline \multirow[b]{2}{*}{ Kunnskaper } & $\begin{array}{l}\text { Sykepleiere } \\
(\mathrm{N}=272)\end{array}$ & \multicolumn{2}{|r|}{$\begin{array}{l}\text { Leger } \\
(N=38)\end{array}$} & \multirow[b]{2}{*}{ t-verdi } & \multirow[b]{2}{*}{ P-verdi } & \\
\hline & nitt (SD) & Gjennomsnit & itt $\quad$ (SD) & & & \\
\hline I hvilken grad har du kunnskaper om observasjon & $3 \cap 0$ & (ก 93) & 353 & $(0.86)$ & -330 & ח \\
\hline $\begin{array}{l}\text { av abstinens-symptomer hos rusmisbrukere? } \\
\text { I hvilken grad har du kunnskaper om be- }\end{array}$ & 3,00 & $(0,43)$ & 3,53 & $(0,86)$ & $-3,30$ & U,UU1 \\
\hline $\begin{array}{l}\text { handling av abstinenser hos rusmisbrukere? } \\
\text { I hvilken grad har du kunnskaper om }\end{array}$ & 2,60 & $(0,91)$ & 3,26 & $(0,79)$ & $-4,28$ & $<0,001$ \\
\hline smertelindring til rusmisbrukere? & 2,46 & $(0,84)$ & 3,03 & $(0,59)$ & $-3,97$ & 0,000 \\
\hline $\begin{array}{l}\text { I hvilken grad har du kunnskaper om substitu- } \\
\text { sjonsbehandling med opioider til rusmisbrukere? }\end{array}$ & 2,31 & $(0,92)$ & 2,74 & $(0,79)$ & $-2,72$ & 0,007 \\
\hline $\begin{array}{l}\text { I hvilken grad har du kunnskaper til å skille } \\
\text { mellom rusavhengighet og rusmisbruk? }\end{array}$ & 2,16 & $(0,93)$ & 2,62 & $(0, .92)$ & $-2,86$ & 0,005 \\
\hline
\end{tabular}

Merk: t-test for uavhengige utvalg er gjort for å undersøke mulige forskjeller mellom sykepleiere og leger. Gradering av kunnskap er skåret på en 5 -delt ordinalskala fra 1= lite kunnskap til 5 = mye kunnskap.

$\mathrm{SD}=$ standardavvik

TABELL 3: Holdninger til behandling av opoidavhengige med smerte, forskjeller mellom sykepleiere og leger $(\mathrm{N}=312)$.

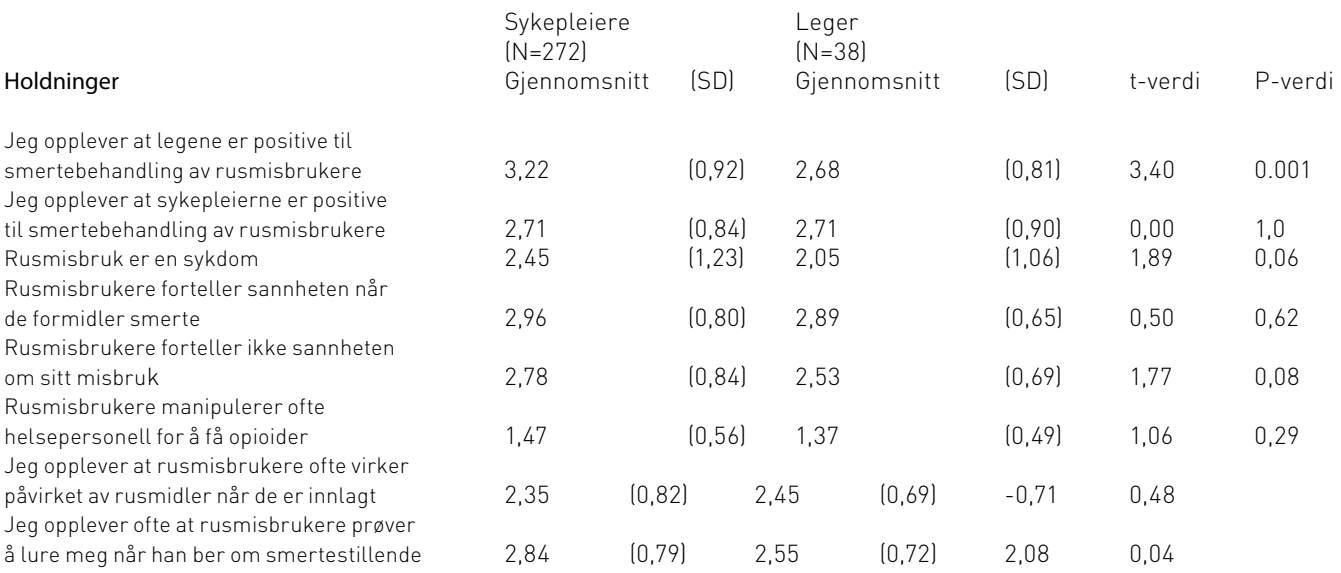

Merk: t-test for uavhengige utvalg er gjort for å undersøke mulige forskjeller mellom sykepleiere og leger. Holdninger er skåret på en 5 -delt ordinalskala fra 1 = helt enig til 5 = helt uenig. $\mathrm{SD}=$ standardavvik

den største gruppen $(44,7$ prosent). Når det gjelder kontakt med rusmisbrukere $\mathrm{i}$ arbeidet, utgjorde de som hadde kontakt med rusmisbrukere én gang per måned eller oftere den største gruppen. Karakteristika ved utvalget $\mathrm{i}$ studien er presentert $\mathrm{i}$ tabell 1.

Handlinger som utføres når opioidavhengige er innlagt i sykehus: Totalt 38 prosent av respondentene oppga at de kartla pasientens rusmisbruk, og leger kartla oftere enn sykepleierne. Denne forskjellen var statistisk signifikant $(p=0,04)$. Det var 46,9 prosent som svarte at de erstattet pasientens daglige bruk av opioider. Totalt 23,2 prosent oppga at de anvendte smertekartleggingsverktøy ofte.

Helsepersonells vurdering av egen kunnskap om opioidavhengighet og smerte: Som det framgår av tabell 2 lå gjennomsnittsverdiene mellom 2,16 og 3 på spørsmålene som handlet om vurdering av egen kunnskap om smertelindring til opio- 
idavhengige. Det var statistisk signifikante forskjeller mellom profesjonene på samtlige spørsmål, og leger vurderte sine kunnskaper bedre enn sykepleierne.

På kunnskapsspørsmålet om opioidavhengige har økt toleranse for opioider, hadde 83,5 prosent riktig svar. På spørsmålet om langvarig bruk av opioider fører til overfølsomhet for smerte svarte 45,3 prosent vet ikke, mens 47,6 prosent svarte at de var enige i påstanden. Det var 70,8 prosent som svarte riktig på spørsmålet om rusmisbrukere trenger store doser opioider for å få effekt. Analyser viste ingen signifikante forskjeller mellom faggruppene i kunnskapsspørsmålene.

Helsepersonells holdninger til opioidavhengige med smerte: Tabell 3 gir en oversikt over studiens hovedfunn. Her framgår det at når legene og sykepleierne ble bedt om å vurdere om legene er positive til smertelindring, vurderte legene dette høyere enn det sykepleierne gjorde. Opplevelsen av å bli lurt av rusmisbrukere når det ble spurt om smertestillende var også mer vanlig blant sykepleierne enn blant legene. Disse forskjellene var statistisk signifikante $(p \# 0,05)$. På de andre holdningsspørsmålene var det ingen statistisk signifikante forskjeller mellom de to gruppene.

Prosentfordeling (ikke framstilt i tabell) viser at 20,8 prosent av sykepleierne og 26,3 prosent av legene var enige eller nokså enige i påstanden om opioidavhengige forteller sannheten når de formidler smerte. Kun 55,7 prosent av sykepleierne og 73,7 prosent av legene var enige $i$ påstanden om at opioidavhengighet er en sykdom. Et flertall (56,1 prosent) av sykepleierne og en sjettedel (15,8 prosent) av legene svarte at de ofte føler seg manipulert av opioidavhengige, og 29,0 prosent av sykepleierne og 36,8 prosent av legene svarte både og på påstanden om at opioidavhengige prøver å lure dem når de ber om smertestillende. Kun dette siste spørsmålet viste statistisk signifikante forskjeller mellom de to yrkesgruppene (tabell 3).

\section{DISKUSJON}

\section{Handlinger og kunnskap}

I denne studien var det et mindretall som kartla pasientens rusmisbruk svært ofte eller ganske ofte, og legene utførte kartlegging oftere enn sykepleierne. Også tall fra internasjonal forskning viser en lav og/eller varierende kartleggingsprosent mellom $18-67$ prosent $(24,35,36)$. Sykepleiernes lave grad av kartlegging i denne studien kan være et uttrykk for at de ikke anser kart- av gjensidig avhengighet $(9,15)$. I Legeforeningens retningslinjer for smertebehandling til opioidavhengige pasienter framgår at det er helt essensielt å kartlegge bruks- og avhengighetstype for å forebygge abstinenser og for å kunne gi adekvat smertelindring (5). Forskning viser at mangelfull kartlegging kan føre til at mange opioidavhengige pasienter blir feildiagnostisert og/eller underbehandlet (13). Årsaker kan være mistillit til pasientens troverdighet og mangel på kunnskap og tid $(25,36)$. I denne studien oppga respondentene et lavt til middels egenvurdert kunnskapsnivå om smertelindring. Legene vurderte sitt kunnskapsnivå høyere enn sykepleierne på alle kunnskapsspørsmålene. På den andre siden var det spesifikke kunnskapsnivået hos begge yrkesgruppene høyt vedrørende toleranse og det

\section{En profesjonell tilnærming er å tro på pasienten, og ikke betvile hans rapport- ering av smerte.}

legging av rusmisbruk som sitt ansvarsområde. En annen mulig forklaring er at sykepleierne mangler kunnskap om hvordan opioidavhengighet kan påvirke smerteopplevelsen og smertebehandlingen, og derfor ikke anser kartlegging som relevant. I likhet med sykepleieres ansvar for observasjoner og vurderinger til ikke opioidavhengige pasienter, bør de også til opioidavhengige pasienter foreta en nøyaktig kartlegging og vurdering av pasientens behov. Vurderingen skal være basert på en systematisk og kontinuerlig innhenting av data. Adekvat smertelindring av opioidavhengige pasienter i sykehus krever et godt tverrfaglig samarbeid, der leger og sykepleiere har komplementære roller preget faktum at rusavhengige pasienter trenger store doser opioider for å få smertelindrende effekt. Tidligere studier har vist at helsepersonell oppgir å ha gode kunnskaper om rusavhengighet, toleranse og hyperalgesi $(25,37)$. På tross av denne kunnskapen får opioidavhengige pasienter ikke mer analgetika enn andre inneliggende pasienter (Ibid). Dette kan tyde på manglende samsvar mellom faktisk kunnskap og anvendelse av denne kunnskapen.

\section{Smertekartleggingsverktøy}

Det var kun en fjerdedel av respondentene som svarte svært ofte eller ganske ofte på spørsmål om bruk av smertekartleggingsverktøy. Mangelfull anvendelse av kartleggingsverktøy ble også 
avdekket i en nylig norsk publisert studie (27). Der fant man at et knapt flertall av nyopererte ikke opioidavhengige pasienter var blitt spurt om å angi sin smerteintensitet på en smerteskala. Sjelden bruk av kartleggingsverktøy kan henge sammen med manglende rutiner, men det kan også knyttes til stigmatiserende, moralistiske og negative holdninger som helsepersonell kan ha til opioidavhengige $(8,12,42)$.

Resultat fra vår studie viste at over halvparten av sykepleierne var enige i påstanden om at opioidavhengige pasienter manipulerer for å få opioider. Smerte er en subjektiv, personlig og privat opplevelse, og det er derfor nødvendig å bruke smertekartleggingsverktøy for å sikre en individuell og optimal smertelindring (44). Bruk av kartleggingsverktøy knyttet til smerte rusmisbrukere som aggressive kan igjen påvirke behandlingen med et gjensidig mistillitsforhold som resultat.

\section{Holdninger}

Et knapt mindretall av respondentene oppga å være usikre eller uenige $i$ at rusavhengighet er en sykdom. Dette samsvarer med resultater fra annen forskning $(20,40)$. Frem til midten av 1990-tallet ble rusavhengighet forstått ut fra et sosialpsykologisk perspektiv, og behandlingen av rusavhengighet lå under sosialtjenesten. Selv om dette perspektivet ble endret fra et sosialt til et biologisk perspektiv i 1997, foreligger det enda holdninger om at rusavhengighet er selvforskyldt $(11,29)$. Dette kan muligens sees $\mathrm{i}$ sammenheng med den allmenne oppfatning at holdninger er vanskelige å

\section{Når helsepersonell betviler pasientens smerteformidling, undergraver de pasien-}

\section{tens troverdighet.}

og avhengighet vurderes å være av essensiell betydning for at opioidavhengige skal få adekvat smertelindring når de er innlagt i sykehus (10). Nøyaktig kartlegging av pasientens smerte kan redusere sjansen for å bli manipulert eller "lurt" (7). Følelsen av manipulering kan true helsepersonells identitet som troverdige profesjonelle yrkesutøvere, og kan påvirke deres beslutningsprosesser ved smertebehandling, noe som igjen kan føre til at pasienten ikke får nødvendig smertelindring $(7,10,17)$. På den andre siden kan konsekvensene av å holde tilbake opioider til opioidavhengige pasienter med smerter føre til at pasientene blir aggressive og vanskelige $(2,30)$. Helsepersonells opplevelse av endre, og at ny kunnskap ikke er integrert $i$ helsepersonells holdningsdannelse. Det er ikke et nytt fenomen at helsepersonells holdninger påvirker den behandling de gir $(13,38)$. Studier har vist at helsepersonell er lite villige til å bruke tid på pasientgrupper som er ansett for å være selvforskyldte i sine lidelser, og dette påvirker behandlingen av pasientene $(14,29)$. Legeforeningen uttrykker bekymring over at rusavhengighet fortsatt ansees som selvforskyldt, og understreker at det er nødvendig med en vesentlig holdningsendring for at rusavhengige pasienter skal få nødvendig behandling (11).

Resultater fra denne studien viste at det var svært få av sykepleierne som mente at legene var positive til smertebehandling av rusmisbrukere, mens noen flere leger mente at sykepleierne var positive til smertebehandling. I første omgang handler dette om i hvilken grad de to yrkesgruppene synes å være villig til å bruke av tid og ressurser overfor denne pasientgruppen. Sykepleierne kan oppleve at de står mye alene med pasientene, og at de får mangelfulle forordninger og lite støtte fra legene. Studier viser at mangelfulle forordninger kan ha sammenheng med at leger er redde for å bli lurt $(10,41)$. Intensjoner kan predikere handlinger (19). Det er derfor grunn til å anta at legenes og sykepleiernes grad av positiv intensjon til smertebehandling kan påvirke deres handlingsvalg. Resultatene fra studien kan antyde at mangelfull smertelindring ikke bare må forstås ut fra kunnskapsmangel, men like mye ut fra hvordan stereotype holdninger og intensjoner kan påvirke handlingsvalget $(14,29)$.

\section{Tillit}

Over halvparten av respondentene $(54,6$ prosent) var enige $\mathrm{i}$ utsagnet om at opioidavhengige pasienter ofte virket ruset, og noe under halvparten oppga at de erstattet pasientenes daglige bruk av opioider. Opioidsubstitusjon kan forhindre abstinenser som er helt sentralt i smertelindring til opioidavhengige pasienter. Abstinenser kan forsterke hyperalgesi og føre til selvmedisinering for å unngå smerter og abstinens (32). På den andre siden er pasienters eventuelle skjulte rusmisbruk mens de er innlagt i sykehus, til stor bekymring for helsepersonell (10). Mangelfull opioidsubstitusjon kan muligens også forstås $\mathrm{i}$ sammenheng med andre sentrale resultater fra studien, som viste at en tredjedel av respondentene 
mente at opioidavhengige pasienter lyver om sitt rusmisbruk, og at et mindretall av respondentene kartlegger pasientens misbruk? Resultatene viste også at en fjerdedel av respondentene var helt eller nokså enig i at opioidavhengige pasienter forteller sannheten når de formidler smerte. Mange opioidavhengige pasienter sier ikke fra om sitt misbruk fordi de er redde for at deres smerteformidling skal oppfattes som russøkende atferd (41). Tidligere studier har vist at helsepersonells kunnskapsmangel, opiofobi og stereotype holdninger er sentrale barrierer som kan påvirke handlingsvalg ved smertelindring til pasienter som ikke er opioidavhengige $(14,28)$. Dersom disse barrierene påvirker smertelindring til dem som ikke er opioidavhengige, kan man spørre seg hvordan dette vil kunne virke inn på smertelindringen til pasienter som er opioidavhengige. Det er grunn til å tro at utilstrekkelig smertelindring forsterkes når pasienten har eller har hatt et problem med rusmisbruk $(5,8)$. Det kan henge sammen med at helsepersonell har vegring mot å gi opioider som analgesi til en som er opioidavhengig, og de kan mistro pasientens rapportering av smerte og tro at de kun er ute etter rus (2).

Når helsepersonell betviler pasientens smerteformidling, undergraver de pasientens troverdighet. Det har vist seg at opioidavhengige pasienter ikke inntar rusmidler i skjul hvis helsepersonell velger å ha tillit til deres rapportering om smerte $(34,41)$. Et gjensidig tillitsforhold opparbeidet gjennom aktiv kommunikasjon er helt sentralt ved smertelindring til denne pasientgruppen (4,9,22,38). En grunn kan være at mange av pasientene har erfaringer som har medført mistillit til helsevesenet. I tillegg er dette en pasientgruppe der mange har hatt en skadelidende sosialiseringsprosess på grunn av omsorgssvikt som kan ha medført mistillit til andre mennesker (45). Det er derfor av essensiell betydning å forsikre pasientene om at de vil få adekvat smertelindring, behandling og forebygging av abstinenssymptomer, i tillegg til lindring av plager og symptomer som følge av abstinens. Da vil sjansen øke for å opprette ett gjensidig tillitsforhold (2).

\section{Svakheter og styrker}

En svakhet ved studien er det egenutviklete spørreskjemaet, som ikke er validert eller testet ut $\mathrm{i}$ andre studier. Holdninger er vanskelig å måle, og det kan reises spørsmål ved begrepsvaliditen i skjemaet. Imidlertid ble holdningsbegrepet operasjonalisert på bakgrunn av en anerkjent holdningsteori (18). I tillegg viste pilottestingen av skjemaet stor grad av samforståelse vedrørende begrepet. Dette styrker mulighetene til å generalisere resultatene. En styrke ved studien er den høye svarprosenten som kan tolkes som at respondentene opplevde temaet som klinisk relevant og vel verdt å bruke tid på. En annen styrke er at utvalget ble rekruttert fra fire sykehus fra fire helseregioner og dermed representerer flere landsdeler. På den andre siden ble utvalget rekruttert fra avdelinger som ofte har opioidavhengige pasienter innlagt. Respondentene i denne studien kan ha gitt andre typer svar enn et utvalg rekruttert fra avdelinger med færre opioidavhengige pasienter innlagt. I spørreskjemaet var kategoriseringen av hvor ofte de var i kontakt med rusmisbrukere ufullstendig og hadde overlappende svaralternativer. Det gjør at vi vanskelig kan trekke noen konklusjoner om betydningen av om helsepersonell har hyppig eller sjelden kontakt med denne pasientgruppen. Etterfølgende studier anbefales å undersøke denne bakgrunnsinformasjon, samt å dekke forskjellige avdelinger; både innen spesialist- og førstelinjetjenesten.

\section{Implikasjoner}

Resultatene i denne studien indikerer at det kan være behov for holdningsendrende tiltak, undervisning og klinisk integrert læring, som har vist seg å høyne kunnskapen hos helsepersonell innen dette området. Solid kunnskap er essensielt for å ivareta krevende pasientgrupper med komplekse hjelpebehov $(17,43)$. Like viktig er en avdelingskultur som fremmer utvikling av og refleksjon rundt personlig kompetanse (23). Det er nødvendig at ruspolitiske endringer som rusreformen og LAR, og individuell plan blir implementert i kliniske beslutningsprosesser.

\section{KONKLUSJON}

Fordi helsepersonells holdninger til en viss grad synes å trekke pasientens troverdighet i tvil, er det behov for videre studier for å undersøke om opioidavhengige pasienter faktisk får adekvat smertebehandling når de er innlagt i sykehus.

\section{REFERANSER}

1. Popova S, Rehm J, Patra J, Baliunas D, Taylor B. Illegal drug-attributable morbidity in Canada 2002. Drug and Alcohol Review. 2007;26:251-63.

2. Haber SP, Demirkol A, Lange K, Murnion B. Management of injecting drug users admitted to hospital. Lancet. 2009;374:1284-93.

3. WHO. Lexicon of alcohol and drug terms published by the World Health Organization 2010. http://www.who.int/ substance_abuse/terminology/who_lexicon/en/. (Nedlastet: 1.11.2011.)

4. Rygnestad T, Krook LA. Behandling 
av opioidavhengige i sykehus. NAForum, Tidsskrift for Norsk anestesiologisk forening. 2006;19:10-13.

5. Den Norske Legeforenings retningslinjer for smertelindring 2009 http://www.legeforeningen.no/ asset/42585/1/42585_1.pdf. (Nedlastet: 1.11.2011.)

6. McCreaddie M, Lyons I, Watt D, Ewing E, Croft J, Smith M., Tocher J. Routines and rituals: a grounded theory of the pain management of drug users in the acute care setting. Journal of Clinical Nursing. 2010;19:2730-40.

7. Alford D.P., Compton P., Samet J.H. Acute pain Management for Patients Reciving Maintenance Methadone or Buprenorphine Therapy. Annals of Internal Medicine. 2006; 144:127-34.

8. Morgan BD. Knowing How to Play the Game: Hospitalized Substance Abuser's Strategies for Obtaining Pain Relief. Pain Management Nursing. 2006;7:31-41.

9. Konsgaard UE, Bell FR, Breivik $H$. Smertelindring ved stoffmisbruk eller langvarig opioidbehandling. Tidsskrift for Norsk Lægeforening. 2005;20:2808-10. 10. Merill JO, Rhodes LA, Deyo RA, Marlatt AG, Bradley KA. Mutual Mistrust in the Medical Care of Drug Users - The Keys to the "Narc" Cabinet. Journal of General Internal Medicine. 2002;17: 327-333.

11. Legeforeningen. På Helsa løs - Når rusbruk blir misbruk og misbruk blir avhengighet. Statusrapport fra Den norske legeforening. 2006. http://www.legeforeningen.no/asset/29556/2/29556_2. pdf. (Nedlastet: 1.11.2011.)

12. Ahern J, Stuber J, Galea S. Stigma, discrimination and the health of illict drug users. Drug and Alcohol Dependence. 2007; 88:188-96.

13. Kelleher S. Health care professionals' knowledge and attitudes regarding substance use and substance users. Accident and Emergency Nursing. 2007;15:161-5.

14. Brockopp DY, Ryan P, Warden S. Nurses' willingness to manage the pain of specific groups of patients. British Journal of Nursing. 2003;12:409-5.

15. Coombs M., Ersser SJ. Medical hegemony in decision-making - a barrier to interdisciplinary working in intensive care? Issues and innovations in nursing practice. Journal of Advanced Nursing. 2004:46:245-52.

16. Befring AK, Ohnstad B. Helsepersonelloven med kommentarer. 2. utgave, Bergen, Fagbokforlaget. 2001.

17. Dewar A., Mullett J., Langdeau, S. Psychiatric Patients: How Can We Decide if You Are in Pain? Issues in Mental Health Nursing. 2009; 30:295-303.

18. Ilstad S. Sosialpsykologi. 5. utgave, Trondheim: Tapir akademisk forlag. 2004. 19. Oppenheim A.N. Questionnaire design, interviewing, and attitude mea- surement. London: Pinter. 1992

20. Weiss L, McCoy K, Kluger M, Finkelstein R. Access to and use of health care: perceptions and experiences among people who use heroin and cocaine. Addiction Research and Theory. 2004:12:155-65. 21. Nylenna M. Publisere \& presentere. Medisinsk fagformidling i teori og praksis. 1. utg. Oslo, Gyldendal Akademisk. 2008.

22. Helfand M, Freeman M. Assessment and Management of Acute Pain in Adult Medical Inpatients: A Systematic Review. Pain Medicine. 2009;10:1183-99.

23. Jahren Kristoffersen N, Nortvedt F. og Skaug E-A.(red). Jahren Kristoffersen N. og Nortvedt P. Kap. 5, Relasjonen mellom sykepleier og pasient. Skaug E-A og Dahl Andersen I. Kap 6, Beslutningsprosesser i sykepleien. Jahren Kristoffersen N. Kap. 7. Sykepleiekunnskap og kompetanse. Grunnleggende sykepleie. Danmark, Gyldendal Akademiske. 2005;137-181, 184-213, 215-256.

24. Happell B. Nurses' knowledge, attitudes and beliefs regarding substance use: A questionnaire survey. Nursing and Health Sciences. 2002; 4:193-200.

25. Kelleher S., Cotter P. A descriptive study on emergency department doctors' and nurses' knowledge and attitudes concerning substance use and substance users. International Emergency Nursing. 2009;17: 3-14.

26. Utdannings- og forskningsdepartementet. Rammeplan for sykepleieutdanningen 2005. http://www.regjeringen. no/upload/kilde/kd/pla/2006/0002/ddd/ pdfv/269376-rammeplan_for_sykepleierutdanning_05.pdf. (Nedlastet: 1.11.2011.)

27. Fredheim $\mathrm{OM}$, Borchgrevink $\mathrm{CP}_{\text {, }}$ Nordstrand B, Clausen T, Skurtveit S. Prescription of analgesics to patients in opioid maintenance therapy: A pharmacoepidemiological study. Drug and Alcohol Dependence. 2011;116: 158-62. 28. Grinstein-Cohen O, Sarid O, Attar D, Pilpel D, Elhayany A. Improvements and difficulties in postoperative pain management. Orthopaedic Nursing. 2009; 28 : 232-239.

29. Natan BM, Beyil V, Neta O. Nurses' perception of the quality of care they provide to hospitalized drug addicts: Testing the Theory of Reasoned Action. International Journal of Nursing Practice. 2009;15:566-73.

30. Wintle D. Pain management for the opioid-dependent patient. British journal of nursing. 2008;17:47-51.

31. Gilchrist G, Moskalewicz J, Slezakova S, Okruhilca L, Torrens M, Vajd R, Baldacchino A. Staff regard towards working with substance users: a European multicentre study. Addiction. 2011;106:1114-25. 32. DuPen A, Shen D, Ersek M. Mechanisms of Opioid-Induced Tolerance and Hyperalgesia. Pain Management Nur- sing. 2007;8:113-21.

33. Sykepleiernes samarbeid i Norden. Etiske retningslinjer for sykepleieforskning i Norden. 2003. http://www.sykepleien.no/ikbViewer/Content/337889/ SSNs\%20etiske\%20retningslinjer.pdf. (Nedlastet: 1.11.2011.)

34. Berg KM, Arnsten JH, Sacajiu G, Karasz A. Providers' Experiences Treating Chronic Pain among Opioid-Dependent Drug Users. The Journal of General Internal Medicine. 2009;24:482-8.

35. Stein M, Wilkinson J, Berglas N, O'Sullivan, P. Prevalence and Detection of Illicit Drug Disorders among Hospitalized Patients. American Journal of Drug \& Alcohol Abuse. 1996:22:463-71.

36. Lappalainen-Lehto R., Seppä K., Nordback I. Cutting down substance abuse-present state and visions among surgeons and nurses. Addictive Behaviours. 2005;30:1013-8.

37. Hines S., Theodorou S, Williamson A, Fong D, Curry K. Management of acute pain in methadone maintenance therapy in-patients. Drug and Alcohol Review. 2008;27:519-523.

38. Hopper JA, Shafi T. Management of the hospitalized injection drug user. Infectious Disease Clinics of North America. 2002;16:571-87.

39. Mitra S, Sinatra, RS. Perioperative Management of Acute Pain in the Opioiddependent Patient. Anesthesiology. 2004:101:212-27.

40. Tang Yi-L, Wiste A, Mao P-X, Hou Y-Z. Attitudes, knowledge and perceptions of Chinese doctors toward drug abuse. Journal of substance Abuse Treatment. 2005;29:215-20.

41. Baldacchino A., Gilchrist G, Fleming R., Bannister J. Guilty until proven innocent: a qualitative study of the management of chronic non-cancer pain among patients with a history of substance abuse. Addict Behaviour. 2010;35:270-2. 42. Ene KW, Nordberg G, Berg I, Johanson FG, Sjøstrøm B. Postoperative pain management - the influence of surgical ward nurses. Journal of Clinical Nursing. 2008;17: 2042-50.

43. Coomarasamy A, Khan KS. What is the evidence that postgraduate teaching in evidence based medicine changes anything? A systematic review. BMJ. 2004;329:1017-21.

44. Breivik $H$, Borchgrevink PC, Allen SM, Rosseland LA, Romundstad L, Breivik Hals EK, Kvarstein G, Stubhaug A. Assessment of Pain. British Journal of Anaesthesia. 2008;101;17-24.

45. Aas NM. "Bare som nykter har jeg verdighet" - om rusmiddelavhengiges livs- og omsorgssituasjon. Hovedfagsoppgave, ernæring, helse og miljøfag, Høgskolen i Akershus. 2003.

Les kommentaren på side $\mathrm{xx}$ 》 